\title{
THE RUNOFF'S BEHAVIOR TO DIFFERENT LAND USES IN WATERSHEDS AT NORTHWESTERN PARANA, BRAZIL
}

\author{
Lysias Vellozo da Costa Filho ${ }^{1 *}$, Nivaldo Eduardo Rizzi ${ }^{2}$ \\ ${ }^{1}$ Parana Federal University, Post-Graduation Program, Forest Science Department, Curitiba, Paraná, Brasil - lysias@ iap.pr.gov.br* \\ ${ }^{2}$ Parana Federal University, Forest Science Department, Curitiba, Paraná, Brasil - niva@ufpr.br
}

Received for publication: 17/12/2014 - Accepted for publication: 24/05/2016

\begin{abstract}
The study attempted to evaluate the effectiveness of the forestry ecosystem on the maintenance of the hydrological processes, which participated on soil's erosion. Aimed to support the land use planning and soil's erosion control works. The work was done through of a simulated rainfall experiment replicated on three watersheds of the Northwest region of the State of Paraná, into four land uses. The experiment was developed by comparing the runoff's behavior of the land uses: forest and three agricultural crops (coffee, cassava and pasture). The results showed greatest infiltration coefficient for soils under forest, with significant difference to other land uses studied. These differences showed that unit area with forest cover resulted in 9,71 times less runoff than area with pasture, 7,86 times less runoff than area with coffee, and 5,56 times less runoff than area with cassava. The results show the forest's potentiality to improve the infiltration processes, showing responses that virtually are not possible to be superseded by the management practices adopted on the other cropping systems studied. The study, to define the range of the forest's effect on its environment, is characterized as essential to planning of the forest cover regarding to size area, and spatial distribution.
\end{abstract}

Keywords: Forestry ecosystem services; runoff determination; soil's erosion control.

\section{Resumo}

O comportamento do escorrimento superficial para diferentes usos da terra em bacias hidrográficas do noroeste do Paraná, Brasil. O estudo avaliou a efetividade do ecossistema florestal na manutenção dos processos hidrológicos que participam da erosão. Objetivou dar suporte ao planejamento do uso da terra e eficiência ao controle da erosão do solo. O trabalho foi realizado através de um experimento de chuvas simuladas repetidas em três bacias hidrográficas da região noroeste do estado do Paraná. O experimento comparou o comportamento do escoamento superficial em quatro diferentes usos da terra: floresta e três culturas agrícolas (café, mandioca e pastagem). Os resultados apresentaram maiores coeficientes de infiltração nos solos com cobertura florestal, com significativas diferenças para os usos da terra estudados. Essas diferenças mostraram que unidades de áreas com cobertura florestal resultaram em 9,71 vezes menos escoamento superficial que áreas com pastagens, 7,86 vezes menos escoamento superficial que áreas com café e 5,56 vezes menos escoamento superficial que áreas com mandioca. Os resultados identificaram a potencialidade da floresta na melhoria da infiltração, apresentando respostas com pouca probabilidade de serem superadas pelas práticas de manejo adotadas nos cultivos estudados. $\mathrm{O}$ estudo, ao definir a dimensão dos efeitos da floresta no seu meio físico, caracteriza-se como essencial ao planejamento da extensão e da espacialização da área florestal.

Palavras-chave: Serviços do ecossistema florestal; determinação do escoamento superficial; controle de erosão do solo.

\section{INTRODUCTION}

Land use by agricultural system can modify the natural landscape resulting in alterations in the spatial pattern of the vegetation, and in the soil's physical properties. These modifications can significantly impact the hydrologic process of water runoff/infiltration into the soil surface within a watershed bringing about accelerated soil erosion (SHELTON, 1981; BRUIJNZEEL, 2004; GERTEN et al., 2004; LUDWIG et al., 2005; SUTHERLAND; ZIEGLER, 2006; BAUTISTA et al., 2007). The destructive process of erosion diminishes fertility and degrades soil structure, reduces the effective root depth, and destroys the most basic natural resource, the water; altering its quality and promoting rivers sedimentation (LAL, 2003)

According to FISRWG, 1998, erosion and sedimentation processes are determined by water that reaches the soil surface in excess of its infiltration capacity and results in runoff. Infiltration is the positive term of the soil's water supply mechanism, it is the variable that influences the ground water recharge, diminishes the loss of

FLORESTA, Curitiba, PR, v. 46, n. 3, p. 413 - 424, jul. / set. 2016.

Costa Filho, L. V. da; Rizzi, N. E.

ISSN eletrônico 1982-4688

DOI: $10.5380 /$ rf.v46i3.39047 
the soil's superficial layers by the erosion, and partitions runoff into slow and fast fluxes (ILSTEDT et al., 2007). The occurrence of an increase in discharge of the Tocantins River can be ascribed to the infiltration reduction and the consequent runoff increase during the rainy seasons, following the soil cover shift (COSTA et al., 2003).

The water resources on a watershed are not only the result of the climatic conditions and geomorphologic structures, but also and in large part, the result of the evolution of the biological succession in the watershed (ZALEWSKI, 2002). In the same way that temporal and spatial scale of hydrological dynamics supports many ecological patterns, the number and diversity of plant functional groups, and the variation and structural complexity of the vegetation can potentially affect the hydrological process (RODRIGUEZ-ITURBE, 2000; BAUTISTA et al., 2007). In addition, there are positive impacts and reciprocal support mechanisms, which link the water to the vegetation through structures whose dynamic characteristics depend on the interrelations between climate, soil and vegetation (PORPORATO; RODRIGUEZ-ITURBE, 2002; DEXTER, 2003; WILCOX et al., 2003).

Previous studies have investigated the mechanisms responsible for soil water dynamics (CAMEIRA et al., 2000; GREGO, 2002; BORMANN; KLAASSEN, 2008), and a significant number of these studies showed functional interrelationships between hydrology and the organisms present in the watershed (ZALEWSKI et al., 1997; RODRIGUEZ-ITURBE，2000; JANAUER，2000; ZALEWSKI， 2000; ZALEWSKI， 2002; PORPORATO; RODRIGUEZ-ITURBE, 2002; WILCOX et al., 2003). The results of the these studies demonstrate, that vegetation patterns are dependent on water distribution and concentration in ecosystems, at the same time vegetation patterns directly modify the nature of water runoff and subsequently the distribution and concentration of water (BERGKAMP et al., 1999; VALENTIN et al., 1999). According to Peel et al. (2001), differences in the variability of annual runoff, between the continents are related to the distribution of deciduous (caducifoil) and evergreen (perenifoil) vegetation and not just the difference in total precipitation. Despite the previous studies attempt to identify the interactions between forest and water, many of forest's functional mechanism, related to hydric resource sustainability, remain unclear (ANDREASSIAN, 2004; CALDER, 2007). However, all of the studies demonstrate that forests play important role in the reduction of the runoff in flood peaks (DEFRIES; ESHELMAN, 2004; BAUTISTA et al., 2007).

Afforestation is largely utilized to attenuate water related problems, such as flood control, landslides, soil erosion, pollutant transport to rivers and even global warming (VAN DIJK; KEENAN, 2007). Forest establishment also is used for the objective of improving biological, physical and chemical properties of soils, in order to maintain its fertility, and ensure adequate supplies of high quality water (ILSTEDT et al., 2007). Although public perception that forests are necessary for most of these circumstances has been questioned by part of the scientific community (CALDER, 2007). According to Ellison; Futter; Bishop (2012), several scientific works report a negative impact on water production due to forested areas, in watershed scale. Calder (2007) considers, at greater regional scale and in a global context, that the interaction forest-water develop an essential function on the atmospheric moisture's providing that becomes precipitation in the water cycle.

Finally, what is no doubt clear is that forests are the most important ecosystem services provider to the environment recovery, carbon sequestration, biodiversity maintenance, biofuel, wood, and other social benefits (DEAL; WHITE, 2012). However, forest usually cannot simultaneously produce these multiple services due to existing trade-offs among the forest's competitive functions (WANG; FU, 2013), what occurs is that when the ecosystem management attempts to maximize the production of one ecosystem service often results in substantial declines in the provision of other ecosystem services (BENNETT; PETERSON; GORDON, 2009).

The forest's ecosystem services have different spatial-temporal scale characteristics and corresponding different stakeholders. Rational management decisions depend on local conditions, needs, and underpinning ecosystem processes (WANG; FU, 2013). In Brazil particularly in the Parana State very little planning goes into afforestation, because of the lack of information. Normally it is planned without a clear focusing in desirable values balance that is ecologically possible (KIMMINS, 2008), and that the forest's impacts on hydrologic processes are situation specific, and caution must be exercised when we extrapolate results (WEI et al., 2005). In this way, to recognize the adequate balance between precipitation and runoff/infiltration is essential to control the hydric erosion and the water body's sedimentation in a watershed.

A lack of knowledge about the behavior of the parameters involved in water runoff/infiltration process has complicated making decision to define strategies to be utilized in formulating land use management plan to reach a desirable balance. Thus, becomes important to conduct studies to evaluate the water's runoff behavior, for the different land uses, specially to determine their water runoff rates, which is preponderant when the objective is planning land use, to control the hydric soil erosion in the state of Parana, Brazil.

The hypothesis is that hydrological process of water runoff/infiltration responds differently to diverse agricultural land uses within the down Paranapanema River Watershed. The hypothesis was investigated through a manipulative experiment using a rainfall simulator. The water infiltration rate, was calculated using the Runoff 
versus Precipitation Evaluation Method, where the runoff is collected to determine the infiltration rates, which are given by the difference between the runoff and the precipitation intensity (HOLDEN; BURT, 2002; BROOKS et al., 2003).

\section{MATERIALS AND METHODS}

\section{Study area}

The study area was located in the municipality of Diamante do Norte, in the northwest part of the state of Parana and encompasses the watersheds of the Diamante do Norte River (BHDN), Maria Acorsi River (BHMA) and the Maracanã River (BHMC). The streams are first order (BHMA and BHMC) and second order (BHDN) streams and all are branches of the left bank of the Paranapanema River.

The region presents a type Cfa climate - mesothermic, humid, with no dry season and hot summers. The median temperature of the coldest month is below $18^{\circ} \mathrm{C}$ and the median temperature of the hottest month is above $22^{\circ} \mathrm{C}$ (MAACK, 2002). It is located on the third plateau of the Parana state, which is delimited on the East by the Geral Range and on the West by the Parana River and covers the entire area of the state from North to South (IAP, 1997). The raw material that contributed to the formation of the majority of the soils in this region is represented by "Arenito Caiuá - São Bento series - Cretaceous." The soils in the region had their textures classified as Sand clay loam, presenting median sand concentrations of superior to $75 \%$ throughout the entire area of the watersheds studied. The largest part of the area is occupied by the soil class Red latosol eutrophic $(74.6 \%)$. In the valley bottoms the soil class Red argisol dystrophic (15.7\%) and in the alluvial areas the soil class Gleisol haplic (3.6\%) (IAP/STCP, 2005).

The largest part of the region (95.59\%) shows inclination varying between $0-8 \%$ and only $(3.5 \%)$ shows greater inclination. Altitude varies from $220 \mathrm{~m}$ along the banks of the Paranapanema River to $420 \mathrm{~m}$ at the headwaters of the watersheds (1997).

The existing forests are Seasonal Semidecidous (seasonal forest) that possess vegetation that in the ecological concept is conditioned to a two season climate, one tropical with intense summer rainfalls and another subtropical without dry season, but with physiological dry periods caused by the cold winters (IBGE, 1992). According to Roderjan et al. (2002), this phytogeographic unit was established where in addition to the eventual occurrence of frosts; the flora is conditioned to a period of low pluviometric precipitation, when $20 \%$ to $50 \%$ of the trees that make up the forest canopy lose their leaves, strongly modifying the vegetation physiognomy. The area covered by natural vegetation, seasonal semideciduous forest, represents $12.62 \%$ of the watershed region. The highest index of occupation by forests is found located in BHDN (30.20\%), and the lowest index in BHMC (0.82\%), and the median is located in BHMA (11.29\%). The afforested areas have insignificant indices (less than $0.1 \%$ ).

\section{Agricultural land use}

Cultivation of the region started in the 1940 's, when farmers from other Brazilian states started to cultivate it; attracted by its "high soil quality" especially suitable for planting coffee (which dominated the economic cycle at the time). With the decline of the coffee culture and its demand for fertile soils, temporary cropping and finally pasture, which currently dominates the regional landscape, were substituted for coffee crops. The pastures and cropping occupy $80.04 \%$ of the total area of the watersheds. BHDN has the smallest occupation (63.64\%), due to EEC's forest area. BHMA (80.44\%) and BHMC (91.48\%) occupation are within the range of the average for the region. Occupation of the lands was fast and little concern was given to preservation of a minimum forest cover. Apparently, at that time, it was not observed that the soil classes of the region presented serious restrictions to intensive use, mainly due to the accentuated erosion susceptibility.

\section{Rainfall simulator design}

The artificial precipitations were executed using a Gottingen type Drop Forming Rainfall Simulators produced in 1984 by the Agronomic Institute of the State of Parana (IAPAR) in partnership with the University of Goettingen and Deutsche Gesellschaft für Technische Zusammenarbeit (GTZ), to conduct hydrological erosion studies in different soil management regimes (ROTH et al., 1985). This Goettingen model that are indicated for studies of factors that influence infiltrability, adds to this characteristic the possibility to produce drops that have terminal energy and size similar to those found in natural rains. The simulator is able to produce different precipitation intensities, which are uniform throughout the sample area. Moreover, it is possible to measure during windy periods, it only consumes a small volume of water, it is energy independent, and additionally it is mobile and easy to operate (ROTH et al., 1985).

The main components of the rainfall simulator are described by the author as being formed by: four (4) vertically mounted steel angle irons $3 \mathrm{~m}$ long (A), which support structure (B) where the PVC reservoir (C) is mounted. The height of the reservoir is adjustable. From this reservoir, capillary tubes made of polyethylene (D) 
are attached to a $68 \mathrm{~cm}$ x $68 \mathrm{~cm}$ distribution plate made of PVC (E). To control the water level, a reference tube is attached to the reservoir (F). Possible blockages of the capillary tubes by air bubbles can be avoided using compressed air to remove them. For this reason the hermetically sealed top of the reservoir has a bicycle type needle valve to permit attachment of a bicycle pump. The water level in the reservoir is maintained by a 40 liter metallic water tank located above the reservoir.

An aluminum top ( $\mathrm{J})$ is attached below the distribution plate to collect the drops until the simulated rainfall has been calibrated, the water collected in this top is directed to recipient (K). To start to apply precipitation, the top is rotated down. The water tank and the reservoir are filled with a manual water pump.

To produce different drop sizes, three different arrangements of capillary tubes were selected: 289 tubes with internal diameter (ID) of $1 \mathrm{~mm}, 289$ tubes with ID of $0.5 \mathrm{~mm}$ and 578 tubes with an ID of $0.1 \mathrm{~mm}$, all spaced in a $2 \mathrm{~cm}$ offset grid on the distribution plate, in all there are 1,156 individual droplet nozzles. The device is capable of irrigating an area of approximately $0.462 \mathrm{~m} 2(68 \times 68 \mathrm{~cm})$.

The $0.5 \mathrm{~m}$ x $0.5 \mathrm{~m}$ sample area is delimited by a frame built from four $35 \mathrm{~cm}$ tall iron plates, which are buried in the soil in the center of the simulator to a depth of approximately $25 \mathrm{~cm}(\mathrm{~L})$. The internal side of one of the plates has a double gutter with a central drain. The frame is buried to the level of the bottom of the gutter, this ensures that all of the water that runs off of the soil is collected in the gutter and drains out of the frame (M) through the central tube and is subsequently collected in sample container (N) (Figure 1).

The simulator calibration is accomplished by repeated measurements of the precipitation intensity with different adjustments of the water level and reservoir height. These measurements are accomplished for each sample at the beginning and end of the experiment for the purpose of identifying whether the precipitation of each sample was consistent. The median kinetic energy of the rainfall produced by the simulator, for simulated precipitations averaging $120 \mathrm{~mm} \cdot \mathrm{h}^{-1}$ was $6.97 \mathrm{~J} . \mathrm{m}^{-2} \cdot \mathrm{mm}^{-1}$. These values are consistent with energy values obtained in other rainfall simulator of the same type (ROTH et al., 1985; HOLDEN; BURT, 2002; JORDAN; ZAVALA, 2008).

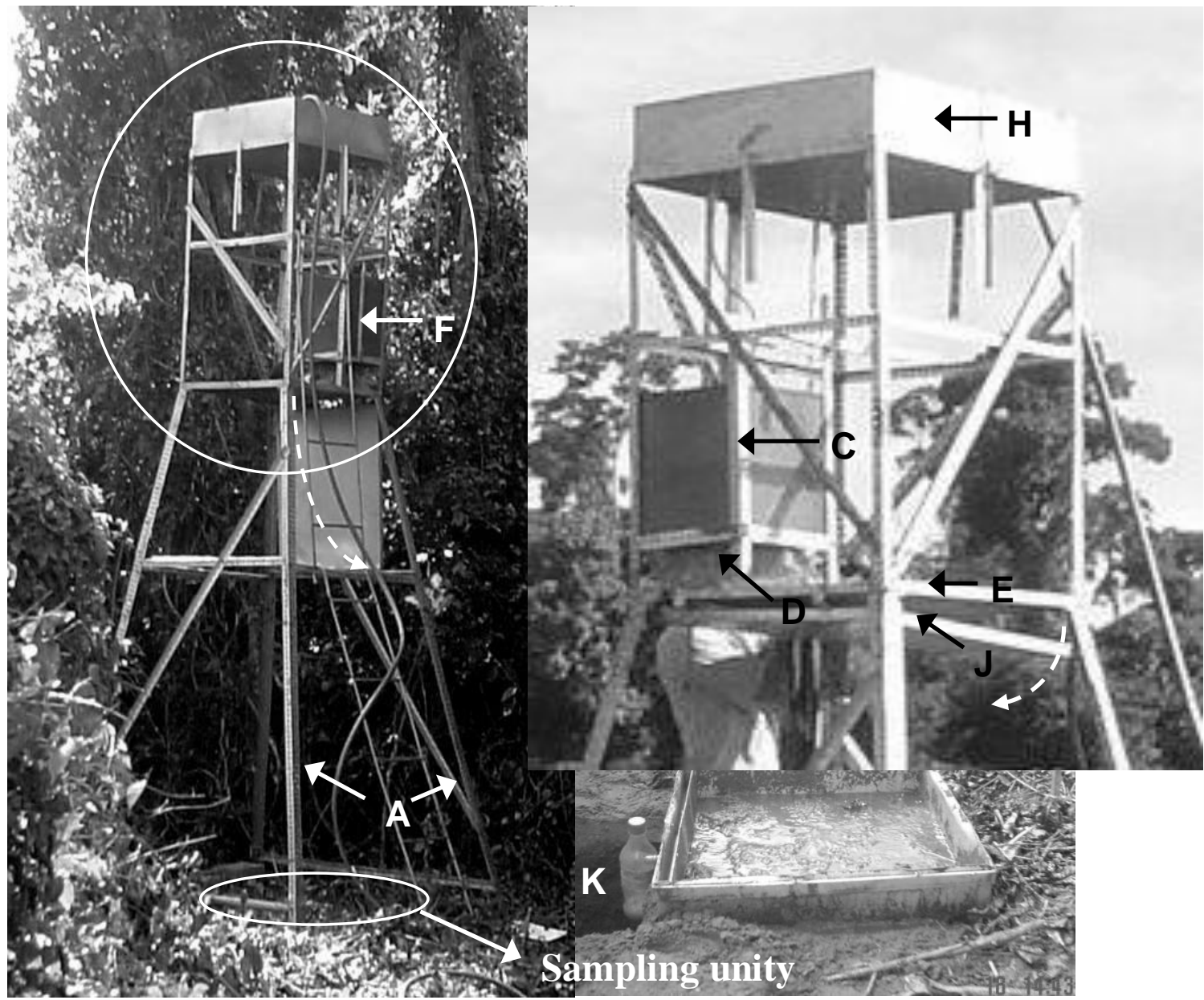


Figure 1. Photographs of the rainfall simulator, with its main elements as described in the text. Detail of the B structure, and of the sample area.

Figura 1. Fotografia do simulador de chuvas, com seus principais componentes descritos no texto. Detalhes da estrutura B e área amostral.

\section{Experimental design}

The experiment was conducted to evaluate the behavior of water runoff/infiltration on three watersheds. The watersheds were sampled once, during the period of April to May 2007. The information about the water runoff/infiltration was obtained through artificial precipitation experiments produced by a rainfall simulator (ROTH et al., 1985; HOLDEN; BURT, 2002; SUTHERLAND; ZIEGLER, 2006; JORDAN; ZAVALA, 2007). The areas of the watershed are occupied by different agricultural system standing out the pastures, the cropping of cassava and coffee aside of the natural forest areas. These detached cropping and the forest areas were defined as treatment.

The selected treatments were characterized by four different cropping sytems: (i) densely planted Coffee (Coffea arabica L.) (C); (ii) conventionally cultivated Cassava (Manihot esculenta Crantz) (M); (iii) Pasture (Brachiaria spp.) (P); and (iv) Forest. All of the cultivated areas, with the exception of the forested areas, utilized conventional soil conservation practices such as terraces and level curves. Data were collected from four sample points randomly located at each treatment (C, F, M, and P). The set of samples was replicated in the three watersheds (BHDN, BHMC, and BHMA), amounting to a total of 48 sample points.

The experiment was conducted using simulated rainfalls, corresponding to an average of $120 \mathrm{~mm} \mathrm{~h}^{-1}$, confirmed at the beginning and end of the simulations for each of the sample points. This high intensity precipitation was used to quickly obtain runoff, and is represent natural extremes in the precipitation typical of the region. The runoff was collected in a $0.5 \times 0.5 \mathrm{~m}$ sampling unit, for a period of one (1) minute at a time, without defined intervals, and measured manually in a graduated cylinder. The data collection were executed until the runoff presented constant rates for ten consecutive measurements, which normally occurred around 60 minutes after the initiation of the precipitations, at the intensities used. The distribution plate of the rainfall simulator was adjusted for each of the sample unities, to be $3.0 \mathrm{~m}$ above the level of the surface of the soil. Whenever the air demonstrated significant movement a protective plastic tarp was used to minimize the effect of the wind below the distribution plate. The water used in the simulations which was obtained from streams in each respective watershed and was also used for human consumption, which allows us to assume that the concentration of solutes was low and that therefore ion exchange did not contribute significantly to the soil erosion process (HOLDEN; BURT, 2002). The collected runoff was deposited in a vase and stored for measurement of sediment concentration.

Soil samples were obtained from three points within the sample sites at five different depths, to determine the soil humidity at the time the runoff samples were taken. The humidity was determined by the ratio between the soil water mass that was evaporated in the oven at a constant temperature of $105^{\circ}-110^{\circ} \mathrm{C}$ until reaching a constant mass, and the dry soil mass (EMBRAPA, 1997).

\section{Data analysis}

The runoff data (Es) were collected in units of volume per minute (ml.min-1) and converted into millimeters per hour $\left(\mathrm{mm} \cdot \mathrm{h}^{-1}\right)$. The results obtained for each sample point were calculated as a runoff coefficient (CE) using the equation:

$$
\mathrm{CEs}=(\mathbf{E s} / \mathbf{P p}) \times 100
$$

where Es = runoff volume and Pp = applied precipitation volume (SUTHERLAND; ZIEGLER, 2006; CERDÁ, 2007). The utilization of the CEs permitted elimination of the uncontrollable differences caused by varying precipitation intensities applied during the experiment.

The following parameters were analyzed from the runoff data for each sample point: Runoff Coefficients (CEs); Runoff Start Time (tiEs); Runoff Stabilization Time (tmEs); and the last ten Runoff Coefficients measured after runoff stabilization (estEs) (JORDAN; ZAVALA, 2008). As suggested by Holden; Burt (2002), the average of the estEs is considered to be the best result to represent the runoff and infiltration rates for simulated precipitation events, as the oscillations observed during the runoff measurement process, in a specific sense (somewhat), cannot be attributed directly to the infiltration process, but are attributable to artificial results due to the data collection method utilized.

A Coefficient of Infiltration (CI) was calculated by subtracting the volume of applied precipitation $(100 \%)$ from the runoff coefficient. Or in other words: 


$$
\mathrm{CI}=100-\text { CEs }
$$

Calculation of CI permitted the elimination of the possible influences of evaporation and more important, the storage effects in depressions and on the existing vegetation on the soil surface (HOLDEN; BURT, 2002).

Spearman correlation coefficients were calculated to examine the relationship of the calculated CEs and the raw data of the Es. Which were considered significant for correlations that presented $p<0.05$. All statistical analyses were conducted utilizing the statistical software SAS (SAS INSTITUTE, 2003); STATISTIC version 7 (STATSOFT INC, 2001).

The effects of the different cropping systems on water runoff were evaluated by statistical analysis. The assumption of normality and homoscedasticity were tested using the Shapiro-Wilk and Levene tests respectively.

The analyses of individual variables of the data set were conducted using the non-parametric test, Kruskal-Wallis $(\mathrm{P}<0.05)$. Once significant effects of the treatments were observed $(\mathrm{P}<0.05)$ the variables were submitted to the non-parametric Mann-Whitney test to verify the difference between the land use systems.

The Bonferroni adjustment was applied, and adjusted to maintain the error indices of the experiment at the specific level of $(\alpha=0.05 ; 5 \%)$. This was done by dividing the level of the $\alpha$ by the number of pairs of comparisons, for the present study and the number of the six (6) pairs (CxF; CxM; CxP; FxM; FxP and MxP). As such, for any comparison to be considered significant the $\mathrm{P}$ value obtained must be less than $\alpha$ critical $=$ $0.0083(0.05 / 6)$, and not 0.05 . This adjustment diminished the chances of having Type I error to acceptable levels (HOLDEN; BURT, 2002).

\section{RESULTS}

The runoff coefficient (CEs) was calculated for all of the treatments from the runoff results (Es) produced by the experiment. The parameters CEs and Es demonstrate a correlation of 0.9983 ( $p<0.0001$ ), when submitted to the Spearman Correlation Test. The calculated CEs form the database for the statistical analyses proposed by the experiment.

As the majority of the variables did not satisfy these assumptions, non-parametric tests were applied (JORDAN; MARTINEZ-ZAVALA, 2008). The results for the variables when submitted to the non-parametric Kruskal-Wallis test (K-W), revealed that the data sets analyzed came from samples submitted to different treatments, showing the significant effects of land use when comparing (Table 1):

Table 1. Median and standard deviation, by treatment, for CEs in \%; tiEs in min; tmEs in min; estEs in \%.

Tabela 1. Média e desvio padrão, por tratamento, do CE\%; tiEs em min.; tmEs em min.; estEs em \%.

\begin{tabular}{|c|c|c|c|c|c|}
\hline $\begin{array}{l}\text { Treatment } \\
\text { Variables }\end{array}$ & $\mathbf{C}$ & $\mathbf{F}$ & $\mathbf{M}$ & $\mathbf{P}$ & Teste K-W \\
\hline CEs & & & & & $\mathrm{H}=729.20$ \\
\hline Median & $30.57 \mathrm{a}$ & $5.57 \mathrm{c}$ & $21.43 \mathrm{~b}$ & $46.39 \mathrm{~d}$ & $\mathrm{DF}=3$ \\
\hline Standard deviation & 17.57 & 6.29 & 18.27 & 26.80 & $\mathrm{P}<.0001$ \\
\hline . tiEs & & & & & $\mathrm{H}=13.28$ \\
\hline Median & $8.85 \mathrm{ab}$ & $4.67 \mathrm{~b}$ & $10.54 \mathrm{a}$ & $4.22 \mathrm{~b}$ & $\mathrm{DF}=3$ \\
\hline Standard deviation & 8.59 & 4.06 & 6.10 & 2.72 & $\mathrm{P}<.0041$ \\
\hline tmEs & & & & & $\mathrm{H}=21.56$ \\
\hline Median & $58.11 \mathrm{a}$ & $19.46 \mathrm{~b}$ & $58.64 \mathrm{a}$ & $28.55 \mathrm{~b}$ & $\mathrm{DF}=3$ \\
\hline Standard deviation & 27.69 & 23.16 & 16.31 & 14.25 & $\mathrm{P}<.0001$ \\
\hline . estCEs & & & & & $\mathrm{H}=255.32$ \\
\hline Median & $44.014 \mathrm{a}$ & $5.60 \mathrm{c}$ & $31.12 \mathrm{~b}$ & $54.42 \mathrm{~d}$ & $\mathrm{DF}=3$ \\
\hline Standard Deviation & 15.55 & 6.85 & 19.23 & 26.18 & $\mathrm{P}<.0001$ \\
\hline
\end{tabular}

Note: The median values followed by different letters are significantly different $\left(\alpha_{\text {critical }}=0.0083\right)$; CEs $=$ runoff coefficient; tiEs $=$ time to start runoff; tmEs = time to reach the runoff stabilization; estCEs = last ten results of runoff after the stabilization; $\mathbf{C}=$ coffee; $\mathbf{F}=$ forest; $\mathbf{M}=$ cassava $; \mathbf{P}=$ pasture

Mann-Whitney (M-W), complimentary statistical tests suggested a significant difference between the medians, when pairs of treatments (CxF; CxM; CxP; FxM; FxP and MxP) were compared. The Bonferroni adjustment was used, with comparisons being considered significant for $\mathrm{P}$ value less than $\alpha$ critical $=0.0083$ 
The runoff start times (tiEs), varied significantly between the treatments. The median tiEs was least for $\mathrm{P}$ treatment $(4.22 \mathrm{~min})$, followed by $\mathrm{F}$ treatment $(4.67 \mathrm{~min})$ however the differences were not statistically significant. Afterwards came the results for C treatment $(8.85 \mathrm{~min})$ and $\mathrm{M}$ treatment $(10.54 \mathrm{~min})$. Despite of the minus importance to the hydrologic process analyses, the tiEs showed the behavior related to the intervention applied to all treatment with standed out for the forest.

The time to obtain runoff stabilization (tmEs), varied significantly (statistically) between the treatments, and was reached quickest for $\mathrm{F}$ treatment $(19.46 \mathrm{~min})$ followed by $\mathrm{P}$ treatment $(28.55 \mathrm{~min})$, next were $\mathrm{M}$ treatment and $\mathrm{C}$ treatment (58.64 min and $58.11 \mathrm{~min}$, respectively) differences that were statistically significant.

The largest median runoff coefficient (CEs) was calculated for the P treatment $(46.39 \%)$, which was preceded by the CEs for $\mathrm{C}$ treatment $(30.57 \%)$, for $\mathrm{M}$ treatment $(21.43 \%)$ and finally by the smallest, $\mathrm{F}$ treatments $(5.57 \%)$. All of the medians demonstrated statistically significant differences; probability less than $\alpha_{\text {critical }}=0.0083$. The runoff coefficient varied according to the expected pattern for runoff when submitted to high intensity precipitations as were applied.

The results of the estCEs also demonstrated statistical significance when submitted to treatments. P treatments presented the largest medians $(54.42 \%)$, following it was $\mathrm{C}$ treatment $(44.01 \%)$, M treatment $(31.12 \%)$ and lastly $\mathrm{F}$ treatments $(5.60 \%)$. The observed differences in the results for estCEs demonstrated that values for $\mathrm{F}$ treatments were 9.71 times less than the others. The results reached are consistent and are in accordance with others studies of the effects of vegetation cover on the water runoff (DEBANO, 1999; JOHANSEN et al., 2001; RULLI et al., 2006; ZHENG et al., 2008) (Figure 2).
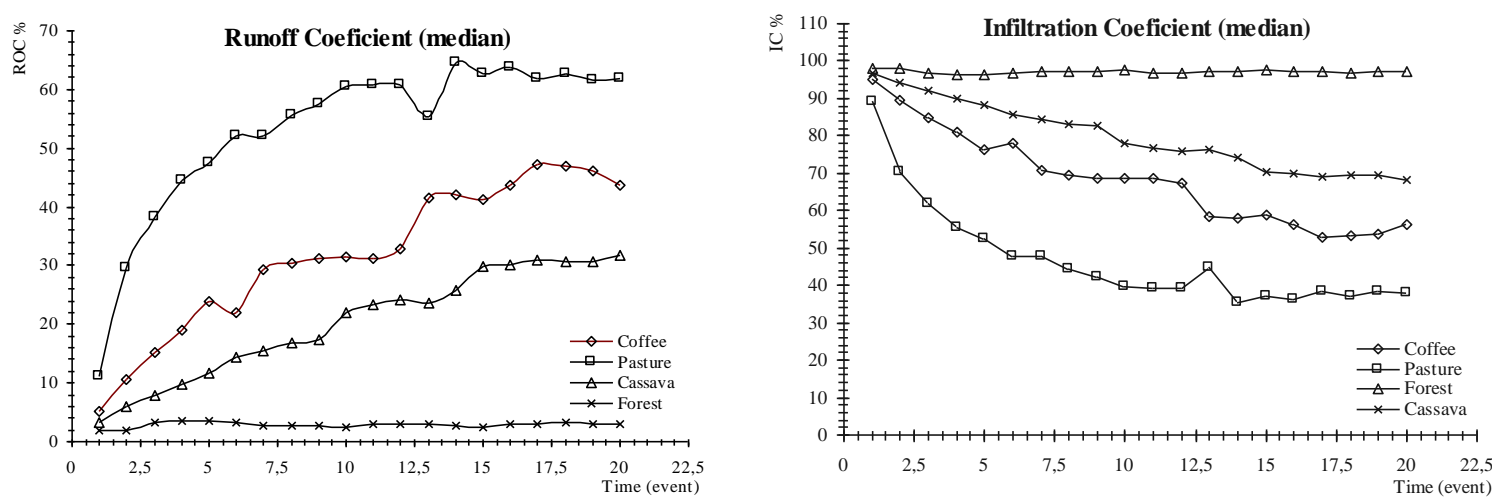

Figure 2. Adjusted medians of runoff coefficient (CEs) and infiltration (CI) for 20 events taken from points equidistant from the time extremes. The Spearman Correlation Test showed a significant correlation between the 20 adjusted medians and the total CES ( $r=0.899873$ and for $\mathrm{p}<0.0001$ ).

Figura 2. Médias ajustadas do coeficiente de escoamento superficial (CEs) e infiltração (CI) de 20 eventos tomados de pontos equidistantes dos tempos extremos. O Teste de Correlação de Spearman mostrou correlação significativa entre as médias ajustadas e o total CEs $(\mathrm{r}=0.899873$ e para $\mathrm{p}<0.0001)$.

Assuming that the simulated precipitation was conducted without interception, which means, the total precipitation reached the soil surface, the apparent Infiltration Coefficients (CI), calculated by equation (8), demonstrated a strong reduction for infiltration capacity of cultivated soils, reaching median values of $45 \%$ of the median precipitation intensity, versus $94 \%$ reached for soil under F treatment (Figure 2).

\section{DISCUSSION}

The experiment results confirmed the prediction that the patterns of water runoff/infiltration into the soil surface of a watershed, would present differences related to the diverse land uses. Also confirmed was the prediction that the behavior patterns of these hydrological processes would present more accentuated alteration corresponding to the land use intensification. The precipitation fraction converted in runoff, documented in the present study, presented higher results for treatments dominated by soil uses considered more intensive $(\mathrm{P}>\mathrm{C}>\mathrm{M})$. The lesser CEs, with expressive differences, up to approximately ten times less, were found in the $\mathrm{F}$ treatment.

The experiment showed CEs values with behavior patterns typical for runoff equations (FOSTER et al., 2000; JORDAN; MASTINEZ-ZAVALA, 2008). The results enable the casual observer to observe the effects of the different land uses and indicate the existence of interactions, interrelations, and reciprocal dependencies of organisms and their physical environment, which are responsible for promoting the mechanism that adequate the 
environment to the needs and development of the species which live there (PORPORATO; RODRIGUEZITURBE, 2002; DEXTER, 2003; WILCOX et al., 2003).

Studies that examine water losses due to runoff as function of the land use, show faster runoff initiation for conditions of more compacted soils (POLYAKOV; LAL, 2004; SUTHERLAND; ZIEGLER, 2006; JORDAN; MASTINEZ-ZAVALA, 2008). In the present study only P treatment revealed compatible values with prior studies, showing shorter times for tiEs, which can be attributed to the compaction of the soil's top layers due to the cattle's trampling (BAGGIO; SCHREINER, 1988; LANZANOVA et al., 2007; MARCHÃO et al., 2007). In the $F$ treatment, despite having soils showing low values for bulk density a rapid initiation for water runoff was observed, without significant difference to $\mathrm{P}$ treatment. This fact is due to the existence of the water repellency phenomenon, which results from the presence of the organic substances accumulated at top layers of the soil (BROOKS et al., 2003). This phenomenon provokes anomalies such as lower infiltration rates at the beginning of precipitation events, these rates increase after some time (DEBANO, 2000; RULLY et al., 2005) (Figure 2). In the $\mathrm{C}$ and $\mathrm{M}$ treatments, although studies of the soil's physical properties report higher values of bulk density for cultivated soils in relation to forest soils (REYNOLDS et al., 2002 and ARAUJO et al., 2004), the observed results show longer times to water runoff initiation, compared to $\mathrm{P}$ and $\mathrm{F}$ treatments. What most likely justifies these obtained results is the fact of that the bulk density of these soils is still under the temporal effect of the agricultural practices adopted (TORMENA et al., 2002).

The time to obtain runoff stabilization (tmEs), that reflects the time interval necessary for soil saturation (POLIAKOV; LAL, 2005), confirms the justification presented for the results obtained for the initiation of water runoff, in $\mathrm{C}$ and $\mathrm{M}$ treatments. In $\mathrm{P}$ treatment, again compactation is responsible for the decrease of the hydraulic conductivity. The F treatment, also, showed a differentiated pattern, but predictable, in view of the fact that in forest soils the runoff rates have a highly variable behavior and, consistently do not occur following the runoff equations patterns (BROOKS et al., 2003).

The median results for the runoff coefficient obtained after its stabilization (estCEs) presented significant correlation with the median values of CEs (Table 1), which assure, indirectly, that these results of estCEs have close relation to other runoff studies, related to vegetation cover (DEBANO, 1999; JOHANSEN $e t$ al., 2001; RULLI et al., 2006; ZHENG et al., 2008), and can represent the runoff/infiltration rate by area unit (HOLDEN; BURT, 2002). Which means, they are values that inform the quantity of water lost to a water body in a watershed for the different treatments (land uses) researched.

Assuming that the simulated precipitation was conducted without interception, which means, the total precipitation reached the soil surface, relative to infiltration capability, the study results show a strong reduction of infiltrability rates for cultivated soils in relation to forest soils. The median CI values which varied from $45.58 \%$ of the precipitation intensity, in $\mathrm{P}$ treatment up to $94.40 \%$ in soils under $\mathrm{F}$ treatment, are compatible with other related studies (DEUCHRAS et al., 1999; SCHWARTZ et al., 2003) (Figure 2), and show that the water infiltration and water flux into soil, in time and volume, occur according to patterns that are determined by the different land uses.

The highest CI values, presented by the F treatment, are a consequence of the higher concentration of organic carbon, the larger extension of the plant root zone, and of the greater presence of burrowing organisms in the soil, which are essential conditions for establishing greater quantities of macropores found in forest soils, in relation to the cultivated soils (REYNOLDS et al., 2002, ARAUJO et al., 2004; DEXTER, 2008). According Zheng et al. (2008), the vegetation type, structure, species composition, and the soil management practices, affect the soil porosity, mainly the pores classified as soil macropores (soil matrix), and the soil continuous macropores (soil structure), which determine the hierarchical order by which the movement of the fluids into soils occur (NIEHOFF et al., 2002; WEILER; NAEF, 2003; WEILER, 2005; BORMANN; KLAASEN, 2008). Soils under other treatments $\mathrm{C}, \mathrm{M}$ and $\mathrm{P}$, showed lesser CI values due to the lower quantities of macropores resulting from soil compactation (RICHARD et al., 2001), the lower presence of organic carbon, and of its lower biological activity (LEONARD et al., 2004; CHAN, 2004; BASTARDIE et al., 2005).

\section{CONCLUSIONS}

- The results showed that land use, with its peculiarities of vegetation type, structure, species composition, and soil management practices, affect differently the processes of the water runoff and infiltration in soil surface.

- The soils under forest showed infiltration rates with significant differences related to the others land uses. The present study documented these differences, demonstrating that forested area result in 9.71 times less runoff than pasture area, 7.86 times less runoff than coffee cultivated, and 5.56 times less runoff than cassava area. These results clearly identify the efficiency of forest cover on runoff retention, showing responses with little probability to be exceeded by the management practices adopted in the other crops studied. 
- The experiment determined trough out of runoff coefficient the precipitation parcel that is converted into runoff for the different cropping systems, as well for native forest cover. The knowledge of these parameter values allows land use planners to define the spatial organization of a watershed in such way to obtain specific and desired infiltration rates. Diminishing, by this way, the runoff potential, and minimizing the erosion and river sedimentation. As the sampling area reached exclusively soil class Red latosol eutrophic, future experiments might be conducted, on others classes of soils, in order to improve the land use management for the study region.

- The results obtained in the present study indicate to land use planners, that to obtain desired infiltration rates it is essential to consider the use of forest covered areas in the spatial organization of the watersheds. The utilization of forest covered areas, with controlled extension and spatialization, characterizes itself as an important instrument to regulate hydrological processes, as well as for biodiversity conservation.

- Applying this management practice in cropping areas, can meet the requirements of environmental laws regarding to the obligation to maintain minimum forested areas.

- Field experiments utilizing the rain simulator proved efficient in data production to analyze the responses of hydrological processes which were affected by different land uses.

\section{REFERENCES}

ANDRÉASSIAN, V. Waters and forests: from historical controversy to scientific debate. Journal of Hydrology, v. 291, p. 1-27, 2004.

ARAuJO, M. A.; TORMENA, C. A.; SILVA, A. P. Propriedades físicas de um latossolo vermelho distrófico cultivado e sob mata nativa. Revista Brasileira de Ciência do Solo, v. 28, p. 337-345, 2004.

BAGGIO, A. J.; SCHREINER, H. G. Análise de um sistema silvipastoril com Pinus elliottii e gado de corte. Boletim de Pesquisa Florestal, EMBRAPA, Colombo, 16, 19-29, 1988.

BASTARDIE, F.; RUY, S.; CLUZEAU, D. Assessment of earthworm contribution to soil hydrology: a laboratory method to measure water diffusion through burrow walls. Biology and Fertility of Soils, v. 41, p. 124-128, 2005.

BAUTISTA, S.; MAYOR, A. G.; BOURAKHOUADAR, J.; BELLOT, J. Plant spatial pattern predicts hillslope runoff and erosion in a semiarid Mediterranean landscape. Ecosystems, 10 (6), 987-998, 2007.

BERGKAMP, G.; CERDA, A.; IMESON, A. C. Magnitude-frequency analysis of water redistribution along a climate gradient in Spain. Catena, 37, 129-146, 1999.

BENNETT, E. M.; PETERSON, G. D.; GORDON, L. J. Understanding relationships among multiple ecosystem services. Ecology Letters, v. 12, p. 1394-1404, 2009.

BORMANN, H.; KLAASSEN, K. Seasonal and land use dependent variability of soil hydraulic and soil hydrological properties of two Northern German soils. Geoderma, 145, 295-302, 2008.

BROOKS, K. N.; FFOLliOTT, P. F.; GREGERSEN, H. M.; DEBANO, L. F. Hydrology and the management of watersheds, $3^{\text {rd }}$ ed. Ames, IO: Iowa State Press. 2003.

BRUIJINZEEL, L. A. Hydrological function of tropical forests: not seeing the soil for the trees? Agriculture Ecosystems \& Environment, 104, 185-228. 2004.

CALDER, I. R. Forest and water - Ensuring forest benefits outweigh water costs. Forest Ecology and Management, v. 251, p. 110-120, 2007.

CAMEIRA, M. R.; AHUJA, L.; FERNANDO, R. M.; PEREIRA, L. S. Evaluating field measured soil hydraulic properties in water transport simulations using the RZWQM. Journal of Hydrology, 236, 78-90. 2000.

CERDA, A. Soil water erosion on road embankments in eastern Spain. Science of the Total Environment, 378 , 151-155. 2007.

CHAN, K. Y. Impact of tillage practices and burrows of a native Australian anecic earthworm on soil hydrology. Applied Soil Ecology, v. 27, p. 89-96, 2004.

COSTA, M. H.; BOTTA, A.; CARDILLE, J. A. Effects of large-scale changes in land cover on the discharge of the Tocantins River, Southeastern Amazonia. Journal of Hydrology, v. 283, p. 206-217, 2003.

DEAL, R. L.; WHITE, R. Integrating forest products with ecosystem services: A global perspective. Forest 
Policy and Economics, v. 17, p. 1-2. 2012.

DEBANO, L. F. 2000. The role of fire and soil heating on water repellency in wildland environments: a review. Journal of Hydrology, 231, 195-206.

DEFRIES, R.; ESHELMAN, K. N. Land-use change and hydrologic processes: a major focus for the future. Hydrological Processes, v. 18, p. 2186-2183, 2004.

DEUCHARS, S. A.; TOWNEND, J.; AITKENHEAD, M. J.; FITZPATRICK, E. A. Changes in soil structure and hydraulic properties in regenerating rain forest. Soil Use and Management, v. 15, p. 183-187, 1999.

DEXTER, A. R. Part I. Theory, effects of soil texture, density, and organic matter, and effects on root growth. Geoderma, 120, 210-214. 2003.

ELLISON, D.; FUTTER, M. N.; BISHOP, K. On the forest cover-water yield debate: from demand- to supplyside thinking. Global Change Biology, v. 18, p. 806-820, 2012.

EMPRESA BRASILEIRA DE PESQUISA AGROPECUÁRIA (EMBRAPA). Manual de Métodos de Análise de Solos. Rio de Janeiro. EMBRAPA. 1997.

FISRWG, The Federal Interagency Stream Restoration Working Group. Stream corridor restoration, principles, processes, and practices, adopted as Part 653 of the National Engineering Handbook, USDANatural Resources Conservation Service USA. 2-1-2-87, 1998.

FOSTER, D. L.; FULLEN, M. A.; BRANDSMA, R. T.; CHAPMAN A. S. Drip-screen rainfall simulators for hydro- and pedo-Geomorphological research: the coventry experience. Earth Surface Processes and Landforms, 25, 691-707, 2000.

GERTEN, D.; SCHAPHOFF, S.; HABERLANDT, U.; LUCHT, W.; SITCH, S. Terrerstrial vegetation and water balance - hydrological evaluation of a dynamica global vegetation model. Journal of Hydrology, 286, 249-270, 2004.

GREGO, R. Preferential flow in macroporous swelling soil with internal catchment: model development and applications. Journal of Hydrology, 269, 150-168, 2002.

HOLDEN, J.; BURT, T. P. Infiltration, runoff and sediment production in blanket peat catchments: implications of fields rainfall simulation experiments. Hydrological Processes, 16, 2537-2557, 2002.

INSTITUTO AMBIENTAL DO PARANÁ (IAP). Plano de Manejo da Estação Ecológica do Caiuá, Diamante do Norte - PR. Paranavaí, Paraná, Brazil. 154 pp. 1997.

/STCP. Avaliação Ecológica Rápida do Corredor Caiuá - Ilha Grande. Curitiba: IAP: STCP Engenharia de Projetos. Curitiba, Paraná, Brazil, 325 pp. 2005.

FUNDAÇÃO INSTITUTO BRASILEIRO DE GEOGRAFIA E ESTATÍSTICA (IBGE). Manual técnico da vegetação brasileira. Rio de Janeiro, RJ, Brazil. 92 pp. Série Manuais Técnicos em Geociências; 1. 1992.

ILSTED, U.; MALMER, A.; VERBEETEN, E.; MURDIYARSO, D. The effect of afforestation on water infiltration in the tropics: A systematic review and meta-analysis. Forest Ecology and Management, 251, 45$51,2007$.

JANAUER, G. A. Ecohydrology: fusing concepts and scales. Ecological Engineering, 16, 9-16, 2000.

JOHANSEN, M. P.; HAKONSON, T. E.; BRESHEARS, D. D. Post-fire runoff and erosion from rainfall simulation: contrasting forests with shrublands and grasslands. Hydrological Processes, 15, 2953-2965, 2001.

JORDÁN, A.; MATÍNEZ-ZAVALA, L. Soil loss and runoff rates on unpaved forest roads in southern Spain after simulated rainfall. Forest Ecology and Management, 255, 913-919, 2008.

KIMMINS, J. P. From science to stewardship: Harnessing forest ecology in the service of society. Forest Ecology and Management, v. 256, n. 10, p. 1625-1635, 2008.

LAL, R. Enhancing crop yields in the developing countries through restoration of the soil organic carbon pool in agricultural lands. Land Degradation \& Environment, v. 17, p. 197-209, 2005.

Soil erosion and the global carbon budget. Environment International, v. 29, p. 437-450, 2003.

LANZANOVA, M. E. Atributos físicos do solo em sistemas de culturas sob plantio direto na integração lavoura-pecuária. Unpublished master thesis, Programa de Pós-Gradução em Ciência do Solo, Centro de 
Ciências Rurais da Universidade Federal de Santa Maria, Santa Maria, Rio Grande do Sul, Brazil. 125 pp. 2007.

LÉONARD, J.; PERRIER, E.; RAJOT, J. L. Biological macropores effect on runoff and infiltration: a combined experimental and modelling approach. Agriculture, Ecosystems \& Environment, v. 104, p. 277-285, 2004.

LUDWIG, J. A.; WILCOX, B. P.; BRESHEARS, D. D.; TONGWAY, D. J.; IMESON, A. C. Vegetation patches and runoff-erosion as interacting ecohydrological processes in semiarid landscapes. Ecology, 86(2), 288297, 2005.

MAACK, R. Geografia Física do Estado do Paraná. 3. ed. Curitiba: Imprensa Oficial do Paraná. 438 pp. 2002.

MARCHÃO, R. L. Integração lavoura-pecuária num latossolo do cerrado: Impacto na física, matéria orgânica e macrofauna. Unpublished doctoral dissertation, Escola de Agronomia e Engenharia de Alimentos da Universidade Federal de Goias, Goiania, Goias, Brazil. 153 pp. 2007.

NIEHOFF, D.; FRITSCH, U.; BRONSTERT, A. Land-use impacts on storm-runoff generation: scenarios of land-use change and simulation of hydrological response in a meso-scale catchment in SW-Germany. Journal of Hydrology, 267, 80-93, 2002.

PEEL, M. C.; MAMAHON, T. A.; FINLAYSON, B. L.; WATSON, G. R. Identification and explanation of continental differences in the variability of annual runoff. Journal of Hydrology, 250, 224-240, 2001.

POLIAKOV, V. O.; LAL, R. Soil erosion and carbon dynamics under simulated rainfall. Soil Science, 1698, 590-599, 2004.

PORPORATO, A.; RODRIGUEZ-ITURBE, I. Ecohydrology - a challenging multidisciplinary research perspective. Hydrological Sciences, 47(5), 811-821, 2002.

REYNOLDS, W. D.; BOWMAN, D. T.; DRURY, C. F.; TAN, C. S.; LU, X. Indicators of good soil physical quality: density and storage parameters. Geoderma, 110, 131-146, 2002.

RODERJAN, C. V.; GALVÃO, F.; KUNIYOSHI, Y. S.; HATSCHBACH, G. G. As unidades fitogeográficas do Estado do Paraná. Ciência e Ambiente, v. 24: 75-92, 2002.

RODRIGUEZ-ITURBE, I. Ecohydrology: A hydrologic perspective of climate-soil-vegetation dynamics. Water Resources Research, 361, 3-9. 2000.

ROTH, C. H.; MEYER, B.; FREDE, H. G. A portable rainfall simulator for studying factors affecting runoff, infiltration and soil loss. Catena, 12, 79-85, 1985.

RULLI, M. C.; BOZZI, S.; SPADA, M.; BOCCHHIOLA, D.; ROSSO, R. Rainfall simulations on a fire disturbed Mediterranean area. Journal of Hydrology, 327, 323-338, 2006.

SAS INSTITUTE. SAS version 9.1 computer software. Cary, NC: SAS Institute, Inc. 2003.

SCHWARTZ, R. C.; EVETT, S. R.; UNGER, P. W. Soil hydraulic properties of cropland compared with reestablished and native grassland. Geoderma, v. 116, p. 47-60, 2003.

SHELTON, M. L. Runoff and land use in the Dechutes Basin. Annals of the Association of American Geographers, 71(1), 11-27, 1981.

STATSOFT, INC. STATISTICA data analysis software system, version 7.1. Retrieve October 24, 2008, from <www.statsoft.com>. 2005.

SUTHERLAND, R. A.; ZIEGLER, A. D. Hillslope runoff and erosion as affected by rolled erosion control systems: a field study. Hydrological Processes, 20, 2839-2855, 2006.

TORMENA, C. A.; BARBOSA, M. C.; COSTA, A. C. S.; GONÇALVES, A. C. A. Densidade, porosidade e resistência à penetração em latossolo cultivado sob diferentes sistemas de preparo do solo. Scientia Agricola, 59(4), 795-801, 2002.

VALENTIN, C.; D'HERBE`S, J. M.; POESEN, J. Soil and water components of banded vegetation patterns. Catena, 37, 1-24, 1999.

VAN DIJK, A. I. J. M.; KEENAN, R. J. Planted forests and water in perspective. Forest Ecology and Management, 251, 1-9, 2007.

WANG, S.; FU, B. Trade-offs between forest ecosystem services. Forest Policy and Economics, v. 26, p. 145$146,2013$.

FLORESTA, Curitiba, PR, v. 46, n. 3, p. 413 - 424, jul. / set. 2016

Costa Filho, L. V. da; Rizzi, N. E.

ISSN eletrônico 1982-4688

DOI: $10.5380 /$ rf.v46i3.39047 
WEI, X.; LIU, S.; ZHOU, G.; WANG, C. Hydrological processes in major types of Chinese forest. Hydrological Processes, v. 19, p. 63-75, 2005.

WEILER, M.; NAEF, F. An experimental tracer study of the role of macropores in infiltration in grassland soils. Hydrological Processes, 17, 477-493, 2003.

WEILER, M. An infiltration model based on flow variability in macropores: development, sensitivity analysis and applications. Journal of Hydrology, 310, 294-315, 2005.

WILCOX, B. P.; BRESHEARS, D. D.; ALEN, C. D. Ecohydrology of a resource-conserving semiarid woodland: Effects of scale and disturbance. Ecological Management, 7(2), 223-229, 2003.

ZALEWSKI, M. Ecohydrology - the scientific background to use ecosystem properties as management tools towards sustainability of water resources. Ecological Engineering, 16, 1-8, 2000.

ZALEWSKI, M. Ecohydrology - the use of ecological and hydrological processes for sustainable management of water resources. Hydrologîcal Sciences-Journal—des Sciences Hydrologiques, 475, 823-832, 2002.

ZHENG, H.; CHEN, F.; OUYANG, Z.; NAIMEI, T.; WEIHUA, X.; WANG, X.; MIAO, H.; LI, X.; TIAN, Y. Impacts of reforestation approaches on runoff control in the hilly red soil region of Southern China. Journal of Hydrology, 356, 174-184, 2008.

ZUMETA, D. C.; ELLEFSON, P. V. Conserving the biological diversity of forest: program and organizational experiences of state governments in the United States. Environmental Management, 26, 393-402, 2000. 